\title{
Model Sinergisitas Kelembagaan dalam Pengembangan Kewirausahaan UMKM Wilayah Perbatasan dengan Pendekatan One Village One Product (OVOP)
}

\author{
M. Irfani Hendri* \\ Fakultas Ekonomi dan Bisnis, Universitas Tanjungpura, Indonesia \\ Vitriyan Espa \\ Fakultas Ekonomi dan Bisnis, Universitas Tanjungpura, Indonesia \\ Hasanudin \\ Fakultas Ekonomi dan Bisnis, Universitas Tanjungpura, Indonesia
}

\begin{abstract}
This study aims to describe the potential of micro, small and medium enterprises (MSMEs) in the border region and to design a model of institutional synergy in the entrepreneurship development of MSMEs in the border region with the approach of one village one product. The approach taken in this study is a qualitative approach with the case study research type. For analysis purposes, data can be collected using triangulation data collection methods involving observation, interview and documentation as well as Focus Group Discussion (FGD). Based on the model developed in the MSMEs entrepreneurship development in border areas, there are 3 (three) institutions that play a role and can synergize with each other, namely business development institutions; village incubator of superior village products and village-owned enterprises.
\end{abstract}

Keywords: entrepreneurship of MSMEs, border regions, OVOP

\section{PENDAHULUAN}

Provinsi Kalimantan Barat merupakan salah satu provinsi di Indonesia yang berbatasan langsung dengan Negara Malaysia, dimana 5 (lima) dari 14 (empat belas) kabupaten/kota yang ada di Kalimantan Barat memiliki wilayah kecamatan yang berbatasan langsung dengan negara bagian Serawak, Malaysia. Kelima kabupaten tersebut adalah Sambas, Bengkayang, Sanggau, Sintang dan Kapuas Hulu. Pada

*Email : irfani2011@yahoo.co.id

Received : 21-05-2018, Accepted : 05-06-2018, Published : 18-08-2018

p-ISSN : 2087 - 9954, e-ISSN : 2550 - 0066. DOI:http://dx.doi.org/10.26418/jebik.v7i2.25717 
umumnya permasalahan yang ada di wilayah perbatasan berkaitan dengan kurangnya infrastruktur yang berakibat terisolirnya wilayah perbatasan dan terbatasnya kesempatan untuk pengembangan dan peningkatan kualitas hidup masyarakat di wilayah perbatasan. Dalam rangka mengatasi permasalahan tersebut, pemerintah saat ini sedang gencargencarnya melakukan pembangunan infrastruktur jalan di wilayah perbatasan. Wilayah perbatasan yang dulu terisolir sekarang saling terhubung dengan pembangunan jalan negara sepanjang 872,14 KM. Dengan pembangunan infrastruktur jalan ini diharapakn dapat semakin meningkatkan kualitas hidup dan kesejahteraan masyarakat di wilayah perbatasan.

Salah satu kecamatan wilayah perbatasan di Kalimantan Barat yang saat ini sedang menikmati kemajuan pembangunan infrastruktur jalan tersebut adalah Kecamatan Sajingan Besar. Kecamatan Sajingan Besar merupakan salah satu kecamatan di Kabupaten Sambas yang berbatasan langsung dengan Negara Bagian Sarawak, Malaysia. Selain Kecamatan Sajingan Besar, Kecamatan Paloh juga merupakan kecamatan di Kabupaten Sambas yang berbatasan langsung dengan Negara Malaysia. Pada saat ini, pembangunan infrastruktur jalan telah menghubungkan Kecamatan Sajingan Besar dengan Desa Temajuk di Kecamatan Paloh dan Kecamatan Jagoi Babang di Kabupaten Bengkayang.

Kecamatan Sajingan Besar memiliki berbagai potensi ekonomi di sektor pertanian, perkebunan dan juga pariwisata. Dengan berbagai potensi yang dimilikinya, pemerintah pusat telah menetapkan Kecamatan Sajingan Besar sebagai salah satu dari 26 Pusat Kegiatan Strategis Nasional (PKSN). Dimana berdasarkan Peraturan Pemerintah No. 26/2008 tentang Rencana Tata Ruang Wilayah Nasional (RTRWN) di Pasal 1 yang dimaksud dengan PKSN adalah kawasan perkotaan yang ditetapkan untuk mendorong pengembangan kawasan perbatasan negara. Salah satu kriterianya adalah bahwa pusat perkotaan tersebut merupakan pusat pertumbuhan ekonomi yang dapat mendorong perkembangan kawasan di sekitarnya.

Kecamatan Sajingan Besar merupakan kecamatan terluas di Kabupaten Sambas dengan luas wilayah 1.391,20 km2 atau sekitar 21,75 persen dari luas wilayah Kabupaten Sambas dengan kepadatan penduduk paling terkecil yaitu 8 jiwa per kilometer persegi (Statistik, 2016). Kondisi ini sesungguhnya dapat dijadikan peluang bagi Kecamatan Sajingan Besar dalam pengembangan pertanian, dimana rata-rata kepemilikan lahan pertanian per rumah tangga menjadi luas. Dengan menggunakan atau mengaplikasikan teknologi tepat guna, proses pengolahan lahan pertanian akan semakin efesien walaupun lahan cukup luas. Minimnya sumber daya manusia (SDM) yang dimiliki oleh Kecamatan Sajingan Besar, semestinya juga dapat diatasi dengan ketersediaan SDM yang dimiliki oleh kecamatan yang merupakan hinterland bagi Kecamatan Sajingan Besar.

Berdasarkan potensi dan kendala yang dimiliki oleh Kecamatan Sajingan Besar, maka diperlukan suatu pendekatan dalam pengelolaan potensi ekonomi wilayah 
perbatasan. Potensi ekonomi daerah menurut Suparmoko (2002), adalah kemampuan ekonomi yang ada di daerah yang mungkin dan layak dikembangkan sehingga akan terus berkembang menjadi sumber penghidupan rakyat setempat bahkan dapat mendorong perekonomian daerah secara keseluruhan. Salah satu pendekatan yang dapat digunakan untuk merancang model pengelolaan potensi ekonomi tersebut adalah one village one product (OVOP). Menurut Dahliani (2009) dan Hendri \& Espa (2013) pengembangan potensi ekonomi dengan konsep OVOP dimaksudkan sebagai pengembangan 1 (satu) produk unggulan di masing-masing desa atau kecamatan termasuk juga wilayah yang menjadi hinterland dengan pola cluster. Sedangkan cluster itu sendiri adalah suatu kawasan/lokasi tertentu dimana terdapat sejumlah usaha mikro, kecil dan menengah (UMKM) yang menggunakan bahan baku yang sama/sejenis untuk menghasilkan produk yang sama, sejenis dan saling terkait.

Akan tetapi, gambaran sebagian besar UMKM di Indonesia termasuk di wilayah perbatasan yang paling dominan adalah rendahnya tingkat produktivitas, rendahnya nilai tambah dan rendahnya kualitas produk. Padahal, produk unggulan yang disyaratkan dalam OVOP harus memenuhi beberapa kriteria yaitu: produk unggulan desa/wilayah dan atau produk kompetensi inti daerah, bersifat unik khas budaya dan keaslian lokal, berpotensi pasar domestik dan ekspor, bermutu dan berpenampilan baik (market oriented), dapat diproduksi secara kontinyu dan konsisten (consistent and sustainable). Selain itu, dalam pengelolaannya, pengembangan ekonomi dengan konsep OVOP menuntut adanya jaringan yang utuh antara pemerintah, dunia usaha, petani, perguruan tinggi, lembaga swadaya masyarakat dan para pelaku pembangunan lainnya (Dahliani, 2009). Berdasarkan permasalahan tersebut, maka diperlukan sebuah model sinergisitas kelembagaan dalam pengembangan kewirausahaan (UMKM) wilayah perbatasan.

Tulisan ini bertujuan untuk mendeskripsikan potensi usaha UMKM yang ada di wilayah perbatasan dan selanjutnya mendesain model sinergisitas kelembagaan dalam pengembangan kewirausahaan UMKM wilayah perbatasan dengan pendekatan One Village One Product (OVOP).

\section{KAJIAN LITERATUR}

\subsection{Pendekatan One Village One Product (OVOP)}

Konsep One Village One Product (OVOP) sudah dikenal sejak Tahun 2001. Pertama kali OVOP diperkenalkan oleh komunitas kota kecil Oita, Jepang yang diterjemahkan sebagai "paling sedikit satu kecamatan menghasilkan satu produk unggulan" (Dahliani, 2009). Di Thailand OVOP lebih dikenal sebagai OTOP, yaitu One Tambon, One Product yang diadopsi oleh pemerintah untuk mengurangi kemiskinan di negara ini.

Pendekatan OVOP merupakan salah satu model pendekatan kawasan sentra produksi (KSP). Program pengembangan KSP merupakan suatu langkah terprogram 
guna memacu kegiatan ekonomi yang berbasis pada komoditas unggulan dan sumber daya alam di suatu wilayah. Dalam pengelolaannya, pengembangan KSP menuntut adanya jaringan yang utuh antara pemerintah, dunia usaha, petani, perguruan tinggi, lembaga swadaya masyarakat dan para pelaku pembangunan lainnya. Di samping itu, pengembangan KSP juga harus sinergis antar komoditas/sektor dan antar kawasan.

Pengembangan KSP harus memenuhi beberapa kriteria, diantaranya : 1) kawasan tersebut memiliki kapasitas dan potensi produksi yang signifikan dan kontinu; 2) kawasan tersebut mampu menyediakan infrastruktur yang memadai untuk meningkatkan produksi dan aksesibilitas kawasan; 3) kawasan tersebut mempunyai sumberdaya manusia (tenaga kerja) yang menguasai teknologi budidaya, pengolahan dan pemasaran; 4) kawasan tersebut terbuka bagi pengembangan lembaga permodalan dan lembaga ekonomi lainnya.

\subsection{Pusat Kegiatan Strategis Nasional dan Konsepsi Kawasan Pengembangan Ekonomi}

Pusat Kegiatan Strategis Nasional (PKSN) adalah kawasan perkotaan yang ditetapkan untuk mendorong pengembangan kawasan perbatasan negara, di mana hal ini didasarkan pada Pasal 1 Peraturan Pemerintah No. 26/2008 tentang Rencana Tata Ruang Wilayah Nasional (RTRWN) . Selanjutnya berdasarkan Pasal 15 PP RTRWN, maka PKSN ditetapkan dengan kriteria 1) Pusat perkotaan yang berpotensi sebagai Pos Pemeriksaaan Lintas Batas (PPLB) dengan negara tetangga; 2) Pusat perkotaan yang berfungsi sebagai pintu gerbang internasional yang berhubungan dengan negara tetangga; 3) Pusat perkotaan yang merupakan simpul utama transportasi yang menghubungkan wilayah sekitarnya dan atau 4) Pusat perkotaan yang merupakan pusat pertumbuhan ekonomi yang dapat mendorong perkembangan kawasan di sekitarnya. Pengembangan PKSN ini dimaksudkan untuk menyediakan pelayanan yang dibutuhkan untuk mengembangkan kegiatan masyarakat di kawasan perbatasan, termasuk pelayanan kegiatan lintas batas negara.

\subsection{Pengembangan Kewirausahaan UMKM}

Sesuai dengan UU No. 20 Tahun 2008 tentang Usaha Mikro, Kecil dan Menengah, usaha mikro adalah usaha produktif milik orang perorangan dan/atau badan usaha perorangan yang memenuhi kriteria usaha mikro sebagaimana diatur dalam Undang-Undang ini. Usaha Kecil adalah usaha ekonomi produktif yang berdiri sendiri, yang dilakukan oleh orang perorangan atau badan usaha yang bukan merupakan anak perusahaan atau bukan cabang perusahaan yang dimiliki, dikuasai, atau menjadi bagian baik langsung maupun tidak langsung dari usaha menengah atau usaha besar yang memenuhi kriteria usaha kecil sebagaimana dimaksud dalam Undang-Undang ini. Sedangkan usaha menengah adalah usaha ekonomi produktif yang berdiri sendiri, yang dilakukan oleh orang perseorangan atau badan usaha yang bukan merupakan anak perusahaan atau cabang perusahaan yang dimiliki, dikuasai, atau menjadi bagian baik 
langsung maupun tidak langsung dengan usaha kecil atau usaha besar dengan jumlah kekayaan bersih atau hasil penjualan tahunan sebagaimana diatur dalam undang-undang ini. Kriteria UMKM berdasarkan UU No. 20 Tahun 2008 tentang Usaha Mikro, Kecil dan Menengah yang didasarkan pada asset dan omzet dapat dilihat pada Tabel 1.

Tabel 1. Kriteria UMKM Didasarkan Pada Asset dan Omzet

\begin{tabular}{|c|c|c|c|c|c|}
\hline \multirow[t]{2}{*}{ No } & \multirow[t]{2}{*}{ Uraian } & \multicolumn{4}{|c|}{ Kriteria } \\
\hline & & & Asset & & Omzet \\
\hline 1 & Usaha Mikro & & Max 50 juta & & Max 300 juta \\
\hline 2 & Usaha Kecil & $>$ & 50 juta -500 juta & $>$ & 300 juta $-2,5 \mathrm{M}$ \\
\hline 3 & Usaha Menengah & $>$ & 500 juta $-10 \mathrm{M}$ & $>$ & $2,5 \mathrm{M}-50 \mathrm{M}$ \\
\hline
\end{tabular}

Sumber : UU No. 20 Tahun 2008

Agar usaha UMKM dapat naik kelas maka diperlukan pengembangan kewirausahaan UMKM. Salah satu pendekatan dalam pengembangan kewirausahaan adalah dengan pendekatan psychological capital. Psychological capital merupakan pendekatan untuk mengoptimalkan potensi psikologis yang dimiliki oleh individu. Psychological capital juga sangat berperan penting dalam menunjang niat dan minat yang kuat dalam berwirausaha (entrepreneurial intention), dimana entrepreneurial intention menurut Katz dan Gartner dalam Indarti \& Rostiani (2008) yaitu proses pencarian informasi yang dapat digunakan untuk mencapai tujuan pembentukan suatu usaha.

Psychological capital merupakan pendekatan untuk mengoptimalkan potensi psikologis yang dimiliki oleh individu yang dicirikan oleh : (1) adanya kepercayaan diri (self confidence) melakukan tindakan yang perlu untuk mencapai sukses dalam tugastugas yang menantang; (2) atribusi yang positif (optimism); (3) resistensi dalam mencapai tujuan dengan kemampuan mendefinisikan kembali jalur untuk mencapai tujuan, dengan kemampuan mendifinisikan kembali jalur untuk mencapi tujuan jika diperlukan (hope); dan (4) ketika menghadapi masalah dan kesulitan, mampu bertahan dan terus maju (resiliency) untuk mencapai kesuksesan (Luthans, Youssef, \& Avolio, 2007).

\section{METODA PENELITIAN}

\subsection{Pendekatan dan Jenis Penelitian}

Pendekatan yang dilakukan dalam penelitian ini adalah pendekatan kualitatif .Adapun jenis penelitian ini adalah studi kasus (case study). Penelitian ini melibatkan kontak langsung dengan obyek penelitian, bersifat detail dan menyeluruh (holistic). Dalam penelitian studi kasus, peneliti merupakan instrument riset utama. Untuk keperluan analisis, data dapat dikumpulkan dengan menggunakan metode pengumpulan data triangulasi (triangulation) yang melibatkan observasi, interview dan dokumentasi (Yin, 1996). 


\subsection{Teknik Pengumpulan Data dan Analisa Data}

Pengumpulan data dan informasi yang diperlukan untuk keperluan analisis dilakukan dengan cara: 1) studi dokumentasi, yang ditujukan untuk mendapatkan data sekunder yang dimiliki oleh instansi-instansi terkait; 2) observasi lapangan, yang berupa pengamatan atau peninjauan langsung terhadap wilayah yang menjadi lokasi penelitian; 3) teknik wawancara, dimana teknik ini dilakukan apabila data atau informasi sebagai bahan masukan tidak terdapat dalam data sekunder; 4) focus group discussion (FGD).

\section{HASIL PENELITIAN DAN PEMBAHASAN}

\subsection{Deskripsi Potensi UMKM di Kabupaten Sambas}

Pertumbuhan Usaha Mikro dan Kecil Kabupaten Sambas pada Tahun 2012 sebesar 98,8 \%, Tahun 2013 meningkat menjadi 98,9\%, Tahun 2014 sedikit mengalami penurunan menjadi 98,85\% dan Tahun 2015 meningkat menjadi sebesar 98,88\%. Pada Gambar 1 dapat dilihat grafik pertumbuhan usaha mikro dan kecil di Kabupaten Sambas Tahun $2012-2015$.

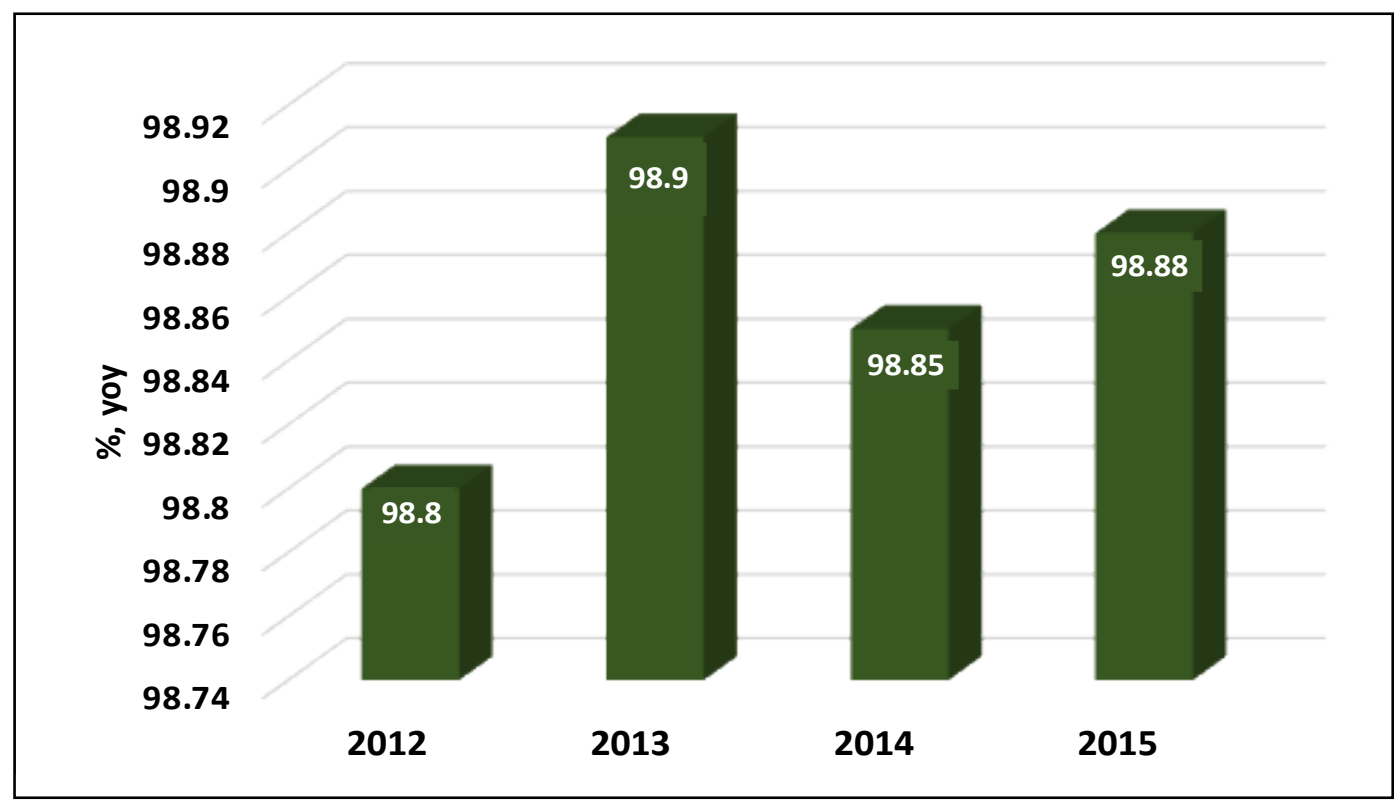

Gambar 1. Grafik Pertumbuhan Usaha Mikro dan Kecil di Kabupaten Sambas Tahun 2012-2015

Berdasarkan Laporan Evaluasi Tahun IV Rencana Pembangunan Jangka Menengah Daerah (RPJMD) Tahun 2012-2016 tersebut juga diketahui bahwa penyumbang utama pertumbuhan usaha mikro dan kecil di Kabupaten Sambas adalah dari sektor usaha kecil, dimana hal ini dapat dilihat pada Gambar 2. Berdasarkan Gambar 
2 dapat dilihat bahwa jumlah usaha mikro di Kabupaten Sambas mengalami penurunan dari Tahun 2014 yang berjumlah 4230 usaha menjadi 4093 usaha mikro pada Tahun 2015. Sedangkan jumlah usaha kecil di Kabupaten Sambas mengalami kenaikan dari 427 usaha pada Tahun 2014 menjadi 959 usaha pada Tahun 2015 .
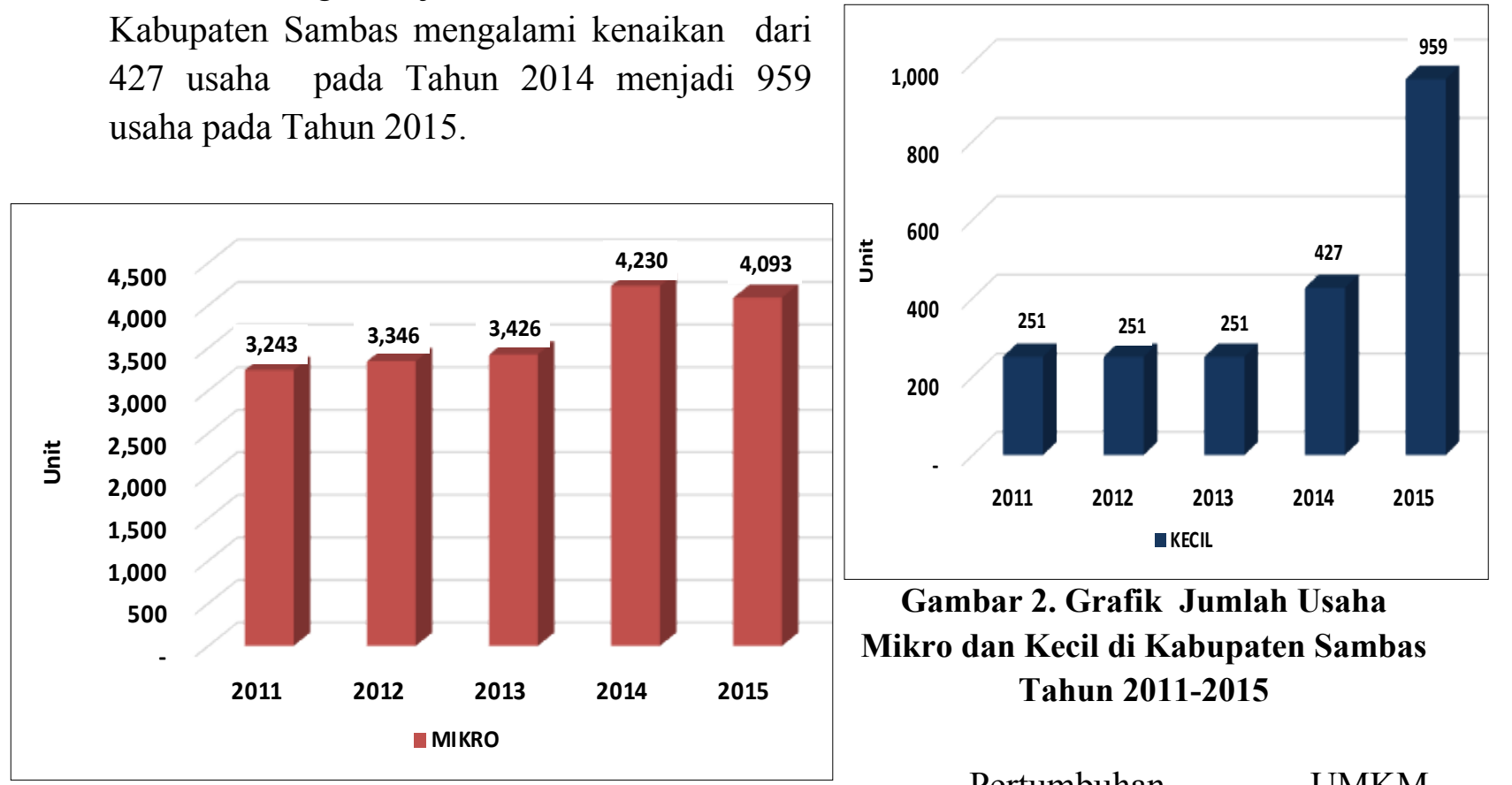

\section{Pertumbuhan}

UMKM

khususnya usaha mikro dan usaha kecil di Kabupaten Sambas dapat menjadi gambaran keseriusan Pemerintah Sambas dalam menjalankan salah satu misi pembangunan Kabupaten Sambas periode 2016-2021 yaitu "Mengembangkan ekonomi kerakyatan dan investasi yang sinergis melalui kemitraan dan pemberdayaan antara pemerintah, swasta, dan masyarakat yang didukung oleh pelayanan prima." Pertumbuhan usaha mikro dan usaha kecil di Kabupaten Sambas ini diharapkan dapat semakin memperluas lapangan usaha serta berdampak pada peningkatan kesejahteraan masyarakat Kabupaten Sambas.

Struktur UMKM di Kabupaten Sambas juga didominasi oleh usaha mikro, walaupun jika didasarkan pada Gambar 2 terlihat bahwa pada Tahun 2015 jumlah usaha kecil di Kabupaten Sambas mengalami peningkatan sedangkan jumlah usaha mikro mengalami penurunan dibandingkan pada Tahun 2014, dimana hal ini dapat dilihat pada Tabel 2.

Tabel 2. Struktur UMKM di Kabupaten Sambas

\begin{tabular}{|c|c|c|c|c|c|c|}
\hline \multirow[t]{2}{*}{ No } & \multirow[t]{2}{*}{ Jenis Usaha } & \multicolumn{2}{|c|}{ Jumlah Unit Usaha } & \multicolumn{3}{|c|}{ Keterangan } \\
\hline & & Tahun 2014 & Tahun 2015 & & & \\
\hline 1 & Usaha Mikro & 4.230 & 4.093 & $\begin{array}{l}\text { Mengalami } \\
\text { usaha }\end{array}$ & penurunan & 137 unit \\
\hline 2 & Usaha Kecil & 427 & 959 & $\begin{array}{l}\text { Mengalami } \\
\text { usaha }\end{array}$ & kenaikan & 532 unit \\
\hline
\end{tabular}


Karena didominasi oleh usaha mikro, maka diperlukan langkah strategis dan taktis serta sinergi dari berbagai pihak agar usaha mikro tersebut bisa mengalami pertumbuhan menuju usaha skala kecil serta usaha kecil menjadi usaha menengah. Langkah strategis dan taktis serta sinergi dari berbagai pihak tersebut tersebut selain diharapkan dapat mewujudkan "UMKM Naik Kelas" juga diharapkan para pengusaha UMKM tersebut dapat menghasilkan produk-produk yang berdaya saing tinggi.

\subsection{Deskripsi Potensi UKM di Kecamatan Sajingan Besar}

Kecamatan Sajingan Besar terletak di bagian Utara Kabupaten Sambas. Sebelah utara Kecamatan Sajingan Besar berbatasan dengan Serawak (Malaysia), di sebelah selatan berbatasan dengan Kecamatan Galing, di sebelah barat berbatasan dengan Kecamatan Paloh dan di sebelah timur berbatasan dengan Serawak (Malaysia).

Berdasarkan data yang ada di Kecamatan Sajingan Besar dalam Badan Pusat Statistik (2016) diketahui bahwa Kecamatan Sajingan Besar merupakan kecamatan yang terluas di Kabupaten Sambas dengan luas wilayah 1.391,20 km2 atau sekitar 21,75 persen dari wilayah Kabupaten Sambas yang terbagi dalam 5 desa yaitu Desa Sebunga, Desa Kaliau, Desa Sanatab, Desa Sentaban dan Desa Sei Bening. Desa Sei Bening merupakan desa terluas dengan luas $557,30 \mathrm{~km} 2$ atau 40,06 persen sedangkan yang terkecil adalah Desa Senatab dengan luas sebesar 110,04 km2 atau 7,91 persen dari luas wilayah Kecamatan Sajingan Besar .

Potensi ekonomi yang dimiliki Kecamatan Sajingan Besar meliputi pertanian dan perkebunan diantaranya karet, kakao dan lada serta pertambangan. Luas tanaman karet di Kecamatan Sajingan Besar adalah 5.921 hektar dengan produksi 2.130 ton, sedangkan kakao dan lada masing-masing memiliki luas 95,00 hektar dan 137 hektar. Pada Gambar 3 dapat dilihat luas area tanaman dan produksi perkebunan menurut jenisnya.

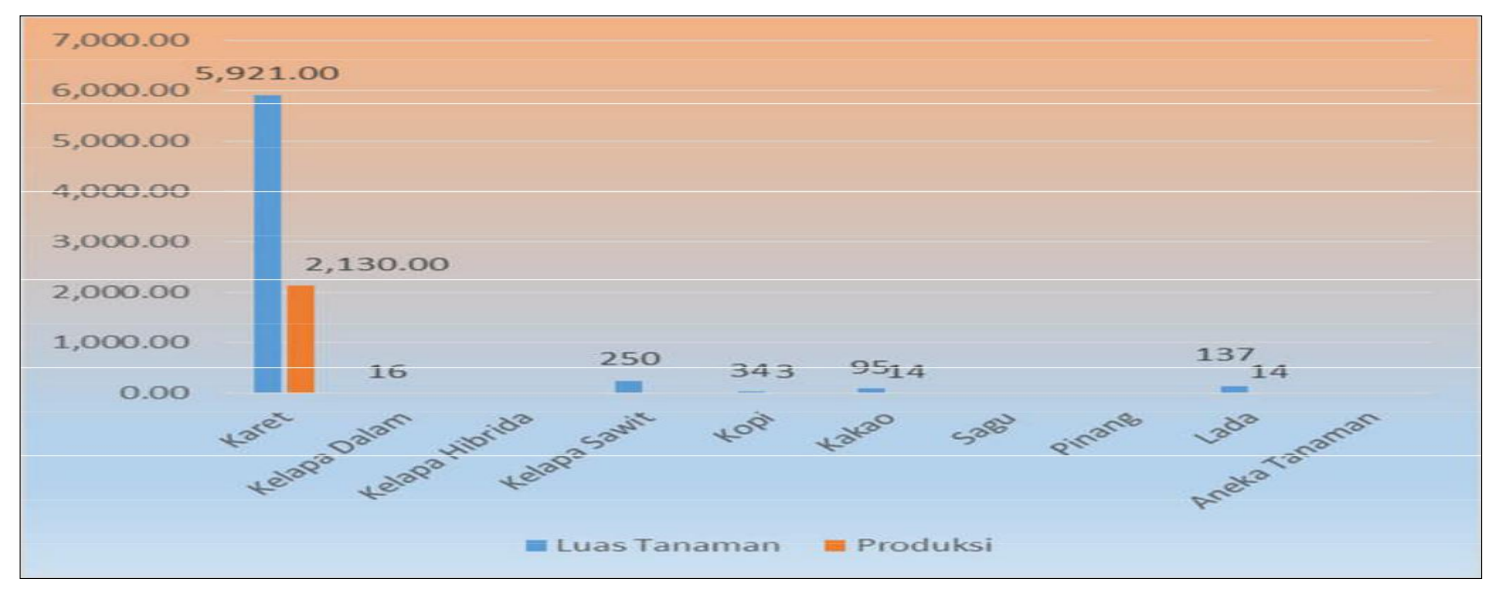

Gambar 3. Luas Area Tanaman dan Produksi Perkebunan Menurut Jenisnya di Kecamatan Sajingan Besar Tahun 2014 
Kecamatan Sajingan Besar juga memiliki potensi pariwisata. Obyek pariwisata yang potensil untuk dikembangkan diantaranya adalah riam berasap di Desa Kaliau dan taman wisata alam di Desa Sei. Bening. Sehingga, dapat dikatakan bahwa sektor unggulan di Kecamatan Sajingan Besar terdiri dari pertanian, perkebunan dan pariwisata. Dengan sumber daya yang dimiliki ini, Kecamatan Sajingan Besar merupakan daerah potensil untuk pengembangan industri pengolahan berbasis hasil komoditi pertanian dan perkebunan (agroindustri).

Namun di sisi lain, Kecamatan Sajingan Besar memiliki keterbatasan dalam jumlah sumber daya manusia (SDM). Berdasarkan angka hasil proyeksi, penduduk Kecamatan Sajingan Besar pada Tahun 2015 berjumlah sekitar 11.114 jiwa dengan kepadatan penduduk sekitar 8 jiwa per kilometer persegi. Pada Gambar 4 dapat dilihat jumlah penduduk Kecamatan Sajingan Besar berdasarkan jenis kelamin.

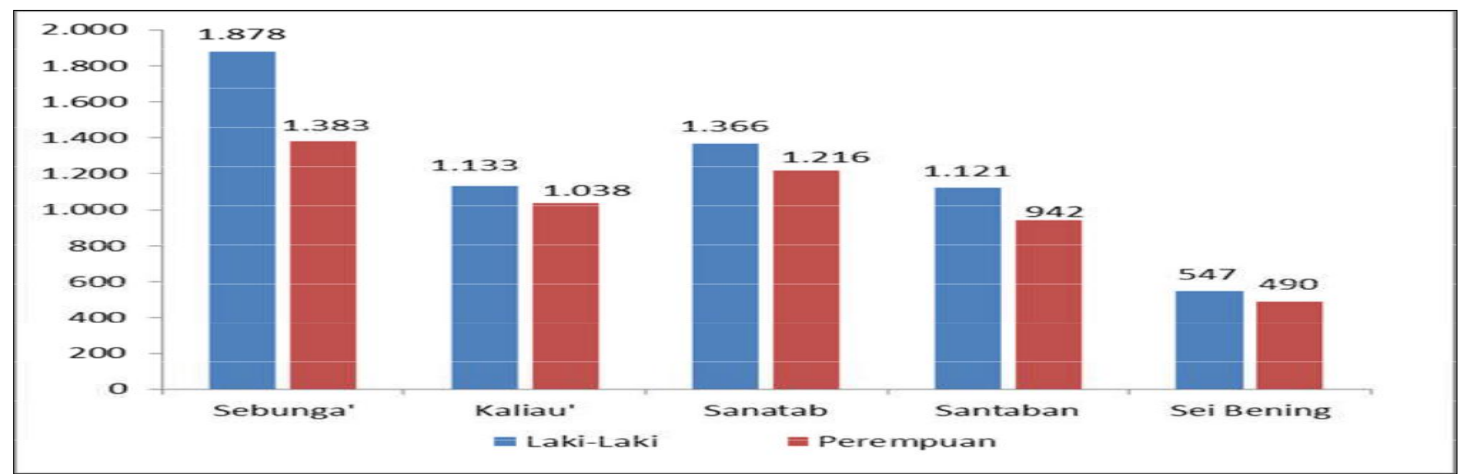

Gambar 4. Jumlah Penduduk Kecamatan Sajingan Besar Berdasarkan Jenis Kelamin Tahun 2015

Karena itu, persoalan mendesak bagi Kecamatan Sajingan Besar adalah minimnya sumber daya manusia untuk mengelola sumber daya alam di daerah yang potensinya amat besar dengan luas wilayah terbesar di Kabupaten Sambas. Walaupun, sesungguhnya hal ini dapat menjadi peluang bagi Kecamatan Sajingan Besar dalam pengembangan pertanian, dimana rata-rata kepemilikan lahan pertanian per rumah tangga menjadi luas. Dengan menggunakan atau mengaplikasikan teknologi tepat guna, proses pengolahan lahan pertanian akan semakin efesien walaupun lahan cukup luas.

\subsection{Model Sinergisitis Kelembagaan Dalam Pengembangan Kewirausahaan UMKM Wilayah Perbatasan Dengan Pendekatan OVOP}

Dalam kaitannya dengan lingkungan eksternal, kawasan perbatasan Kecamatan Sajingan Besar merupakan kawasan strategis dikarenakan memiliki keterkaitan yang bersifat langung dengan Serawak (Malaysia). Artinya, wilayah Serawak mempengaruhi orientasi kehidupan sosial ekonomi penduduk di kawasan Kecamatan Sajingan Besar. Selama ini, antara penduduk di Kecamatan Sajingan Besar dengan penduduk Kota Biawak, Malaysia terjalin aktivitas perdagangan yang cukup tinggi, dimana kegiatan 
perdagangan lintas batas ini sudah berlangsung cukup lama serta dilakukan secara turun temurun. Umumnya kegiatan perdagangan lintas batas meliputi penjualan hasil produk pertanian, perkebunan dan perikanan dan nilai tukar yang digunakan adalah nilai tukar Ringgit Malaysia. Dengan demikian, pengembangan kawasan Kecamatan Sajingan Besar harus bermuara pada kesatuan pandangan bahwa kawasan Kecamatan Sajingan Besar merupakan kawasan spesifik dikarenakan berbatasan langsung dengan wilayah negara tetangga.

Berdasarkan perspektif demikian, pengembangan kawasan perbatasan Kecamatan Sajingan Besar perlu ditempuh melalui model pengembangan secara terbuka, dengan mengedepankan pembangunan pada kawasan cepat tumbuh dan kawasan agropolitan. Hal tersebut perlu dilakukan mengingat kawasan perbatasan Kecamatan Sajingan Besar umumnya memiliki sumber daya alam potensial khususnya di sektor pertanian dan perkebunan yang dapat dikembangkan guna meningkatkan daya saing wilayah perbatasan itu sendiri.

Potensi ekonomi demikian perlu dimanfaatkan secara optimal untuk sekaligus meningkatkan produktivitas ekonomi lokal dan memperluas keanekaragaman kegiatan usaha masyarakat dan dunia usaha. Kondisi ini akan memberikan peluang bagi peningkatan kesejahteraan bagi masyarakat wilayah perbatasan darat IndonesiaMalaysia, khususnya di Kecamatan Sajingan Besar. Potensi lainnya adalah aksesibilitas secara langsung dengan Serawak yang merupakan pasar potensial untuk dimanfaatkan oleh produsen di kawasan Kecamatan Sajingan Besar maupun Kabupaten Sambas dan Kalimantan Barat secara keseluruhan.

Dalam pengembangan berbagai potensi ekonomi tersebut, maka perlu dilakukan pengembangan ekonomi berbasis cluster. Pengembangan ekonomi berbasis cluster ini memiliki tujuan untuk : (1) menumbuhkan potensi masyarakat lokal, dimana hal ini sesuai dengan semangat otonomi daerah, mendorong pertumbuhan wilayah dan juga dapat memberikan sumbangan dalam peningkatan Pendapatan Asli Daerah (PAD), penyediaan tenaga kerja serta mendorong tumbuhnya ekonomi produktif; (2) lebih fokus dalam pembinaan dan pengembangan usaha di setiap desa (cluster); (3) lebih efisien dalam pembinaan; (4) pelaksanaan monitoring dan evaluasi akan lebih mudah dilaksanakan.

Sehingga dalam pengembangan kewirausahaan UMKM di wilayah perbatasan ada 3 (tiga) lembaga yang berperan dan dapat saling bersinergi yaitu 1) Lembaga Pengembangan Bisnis (LPB); 2) Inkubator Desa Produk Unggulan Desa dan 3) Badan Usaha Milik Desa (BUMDes). Adapun infrastruktur yang diperlukan dalam pengembangan ekonomi berbasis cluster ini adalah Lembaga Pengembangan Bisnis (LPB) di setiap cluster. LPB merupakan lembaga yang memberikan jasa layanan pengembangan usaha untuk meningkatkan kinerja usaha cluster, akses pasar, kemampuan bersaing dan juga memberikan pembiayan (permodalan). 
LPB ini dapat dikelola (dimiliki) secara keseluruhan oleh Pemerintah Kabupaten Sambas atau juga dikelola secara bersama-sama dengan pihak swasta. Adapun fungsi dari LPB bagi cluster adalah : 1) layanan informasi bagi cluster; 2) layanan konsultasi, pelatihan dan bimbingan bagi cluster; 3) layanan kontak bisnis (sebagai pemasar bagi cluster); 4) layanan dalam memperluas pasar; 5) layanan dalam pengembangan teknologi dan 6) layanan pembiayaan.

Dalam hal pemberdayaan masyarakat berbasis OVOP ini diperlukan sebuah kelembagaan pemberdayaan di tingkat masyarakat. Pemberdayaan bukan hanya sekedar pendekatan metodologis dalam rangka memandirikan masyarakat sasaran, akan tetapi harus juga diwujudkan dalam bentuk yang lebih konkret sebagai bentuk dari pencapaian sebuah program. Kelembagaan tersebut yang kemudian disebut sebagai Inkubator Desa Berbasis Unggulan Desa. Di mana dengan adanya Inkubator Bisnis di desa ini dapat menciptakan Inovasi Desa, sehingga komoditi yang dijual oleh masyarakat diharapkan secara bertahap dapat dalam bentuk nilai tambah (hilirisasi di desa).

Pendirian BUMDes dilandasi oleh UU No. 32 Tahun 2004 tentang Pemerintah Daerah dan Peraturan Pemerintah No. 72 Tahun 2005 tentang Desa. UU No. 32 Tahun 2004 tentang Pemerintah Daerah: Pasal 213 ayat (1) "Desa dapat mendirikan badan usaha milik desa sesuai dengan kebutuhan dan potensi desa." Selanjutnya Peraturan Pemerintah No. 72 Tahun 2005 tentang Desa: Pasal 78 dinyatakan bahwa :1) Dalam meningkatkan pendapatan masyarakat dan desa, Pemerintah Desa dapat mendirikan Badan Usaha Milik Desa sesuai dengan kebutuhan dan potensi Desa; 2) Pembentukan Badan Usaha Milik Desa sebagaimana dimaksud pada ayat (1) ditetapkan dengan Peraturan Desa berpedoman pada peraturan perundang-undangan; 3) Bentuk Badan Usaha Milik Desa sebagaimana dimaksud pada ayat (1) harus berbadan hukum.

Sehingga model kelembagaan pengembangan potensi ekonomi wilayah perbatasan secara komprehensif dapat dilihat pada Gambar 5 di mana dapat dijelaskan bahwa dalam pengembangan kewirausahaan UMKM di wilayah perbatasan ada 3 (tiga) lembaga yang berperan dan saling bersinergi yaitu 1) Lembaga Pengembangan Bisnis (LPB); 2) Inkubator Desa Produk Unggulan Desa dan 3) Badan Usaha Milik Desa (BUMDes). LPB Merupakan lembaga yang memberikan jasa layanan pengembangan usaha untuk meningkatkan kinerja usaha cluster, akses pasar, kemampuan bersaing dan juga memberikan pembiayan (permodalan) yang berpusat di kecamatan. Sedangkan Inkubator Bisnis Produk Unggulan Desa (IBPUD) merupakan kelembagaan yang berlokasi di desa dan fokus terhadap pengembangan produk unggulan desa (cluster). Dengan adanya IBPUD di setiap desa ini diharapkan dapat mendidik para generasi muda yang ada di desa untuk menjadi seorang wirausaha dan meningkatkan klasifikasi UMKM dari usaha mikro menjadi usaha kecil (UMKM naik kelas).

Selain itu dengan adanya Inkubator Bisnis di desa ini dapat menciptakan inovasi desa, sehingga komoditi yang dijual oleh masyarakat diharapkan secara bertahap dapat dihasilkan dalam bentuk nilai tambah (hilirisasi di desa) dan dapat dijual melalui Badan 
Usaha Milik Desa (BUMDes). Sehingga bisa dikatakan bahwa BUMDes lebih fokus dalam memproduksi dan memasarkan produk hasil inovasi desa yang pemasarannya bisa berorientasi ekspor melalui Border Aruk atau memanfaatkan pasar lokal di kawasan Kecamatan Sajingan Besar maupun Kabupaten Sambas dan Kalimantan Barat secara keseluruhan.

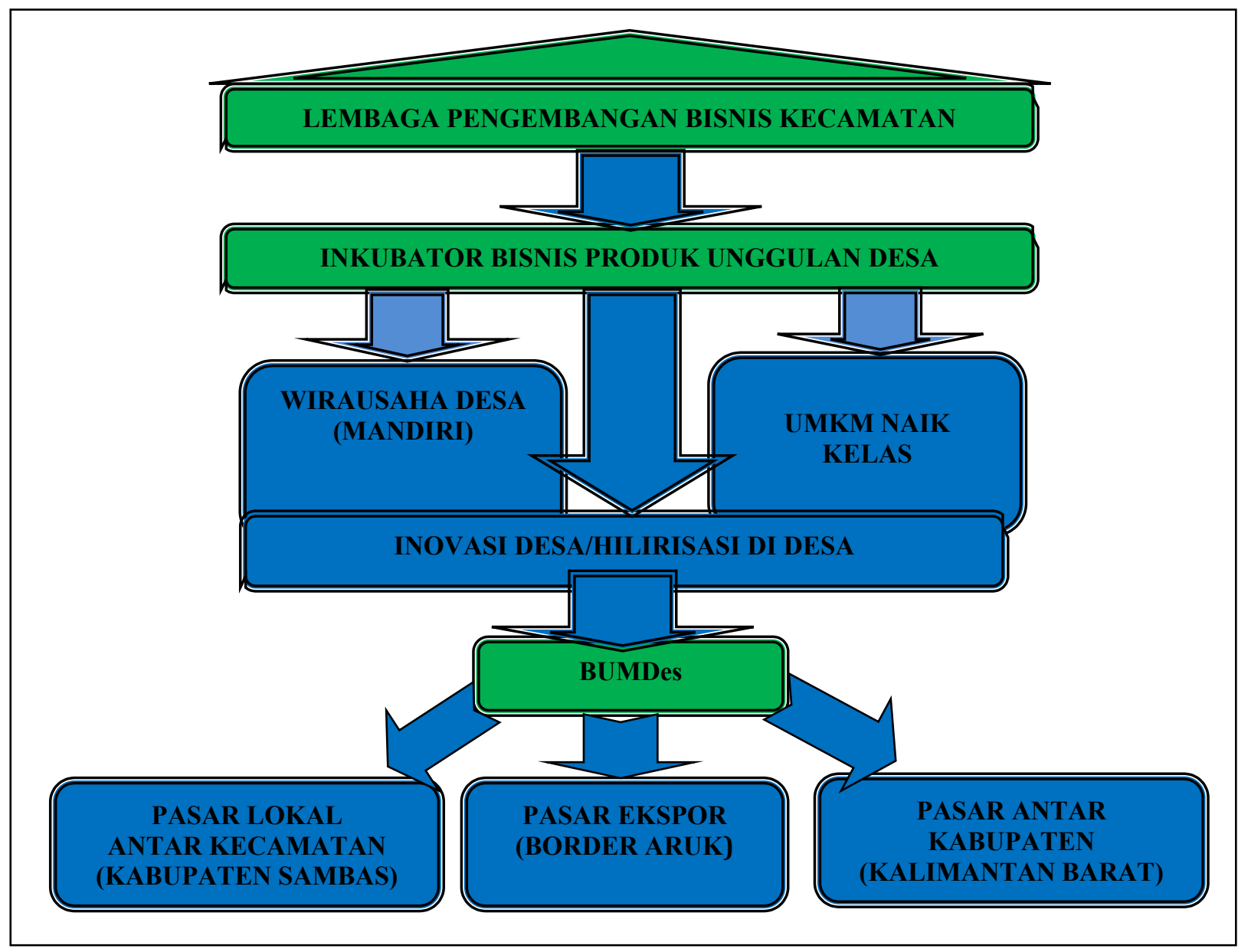

\section{Gambar 5. Model Sinergisitas Kelembagaan Dalam Pengembangan Kewirausahaan UMKM Wilayah Perbatasan}

\section{SIMPULAN}

One Village One Product (OVOP) merupakan salah satu pendekatan yang dapat digunakan untuk merancang model pengelolaan potensi ekonomi. Pengembangan potensi ekonomi dengan konsep OVOP dimaksudkan sebagai pengembangan 1 (satu) produk unggulan di masing-masing desa atau kecamatan termasuk juga wilayah yang menjadi hinterland dengan pola cluster. Gambaran sebagian besar UMKM di Indonesia termasuk di wilayah perbatasan yang paling dominan adalah rendahnya tingkat produktivitas, rendahnya nilai tambah dan rendahnya kualitas produk. Padahal, produk unggulan yang disyaratkan dalam OVOP harus memenuhi beberapa kriteria yaitu: produk unggulan 
desa/wilayah dan atau produk kompetensi inti daerah, bersifat unik khas budaya dan keaslian lokal, berpotensi pasar domestik dan ekspor, bermutu dan berpenampilan baik (market oriented), dapat diproduksi secara kontinyu dan konsisten (consistent and sustainable). Selain itu, dalam pengelolaannya, pengembangan ekonomi dengan konsep OVOP menuntut adanya jaringan yang utuh antara pemerintah, dunia usaha, petani, perguruan tinggi, lembaga swadaya masyarakat dan para pelaku pembangunan lainnya. Oleh karena itu, diperlukan sebuah model sinergisitas kelembagaan dalam pengembangan kewirausahaan (UMKM) wilayah perbatasan.

Dalam pengembangan kewirausahaan UMKM di wilayah perbatasan ada 3 (tiga) lembaga yang berperan dan dapat saling bersinergi yaitu 1) Lembaga Pengembangan Bisnis (LPB); 2) Inkubator Desa Produk Unggulan Desa (IBPUD) dan 3) Badan Usaha Milik Desa (BUMDes). Dengan adanya IBPUD di setiap desa ini diharapkan dapat mendidik para generasi muda yang ada di desa untuk menjadi seorang wirausaha dan meningkatkan klasifikasi UMKM dari usaha mikro menjadi usaha kecil (UMKM naik kelas). Inkubator Bisnis di desa ini ini juga diharapkan dapat menciptakan inovasi desa, sehingga komoditi yang dijual oleh masyarakat diharapkan secara bertahap dapat dihasilkan dalam bentuk nilai tambah (hilirisasi di desa) dan dapat dijual melalui Badan Usaha Milik Desa (BUMDes). Sehingga bisa dikatakan bahwa BUMDes lebih fokus dalam memproduksi dan memasarkan produk hasil inovasi desa yang pemasarannya bisa berorientasi ekspor melalui Border Aruk atau memanfaatkan pasar lokal di kawasan Kecamatan Sajingan Besar maupun Kabupaten Sambas dan Kalimantan Barat secara keseluruhan.

\section{DAFTAR PUSTAKA}

Badan Pusat Statistik. (2016). Kalimantan Barat dalam Angka 2005-2006. Pontianak.

Dahliani, L. (2009). One Village One Product (OVOP). Tinjauan dari Manajemen Produksi Tanaman.

Hendri, M. I., \& Espa, V. (2013). Model Manajemen Pemberdayaan Masyarakat Kawasan Perbatasan Darat Indonesia - Malaysia (Studi Kasus di Kecamatan Sajingan, Kabupaten Sambas). In Prosiding Seminar Nasional \& Call For Paper FMI Ke -5. ISSN : $2338-994 X$.

Indarti, N., \& Rostiani, R. (2008). Intensi Kewirausahaan Mahasiswa: Studi Perbandingan Antara Indonesia, Jepang dan Norwegia. Jurnal Ekonomika Dan Bisnis Indonesia, 23(4), 1-27. https://doi.org/10.22146/jieb.6316.

Luthans, F., Youssef, C. M., \& Avolio, B. J. (2007). Psychological Capital: Developing the Human Competitive Edge. Psychological Capital: Developing the Human Competitive Edge. Oxford University Press. https://doi.org/10.1093/acprof:oso/9780195187526.001.0001.

Peraturan Pemerintah No. 26/2008 tentang Rencana Tata Ruang Wilayah Nasional $(R T R W N)$. 
Peraturan Pemerintah No. 72 Tahun 2005 tentang Desa.

Suparmoko, M. (2002). Ekonomi Publik untuk Keuangan dan Pembangunan Daerah. Yogyakarta: Andi.

UU No. 20 Tahun 2008 tentang Usaha Mikro, Kecil dan Menengah.

UU No. 32 Tahun 2004 tentang Pemerintah Daerah.

Yin, R. K. (1996). Studi Kasus : Desain dan Metode. Jakarta: PT RajaGrafindo Persada. 